\title{
TESTING THE WEAK FORM MARKET EFFICIENCY OF BORSA ISTANBUL: AN EMPIRICAL EVIDENCE FROM TURKISH BANKING SECTOR STOCKS
}

\author{
DOI: 10.17261/Pressacademia.2020.1291 \\ JEFA- V.7-ISS.3-2020(4)-p.236-249 \\ Suadiq Mehammed Hailu ${ }^{1}$, Gamze Vural ${ }^{2}$ \\ ${ }^{1}$ Cukurova University, PhD Candidate in Finance, Adana, Turkey. \\ suadiq1434@gmail.com, ORCID: 0000-0003-3270-1357 \\ ${ }^{2}$ Cukurova University, Department of Business, Adana, Turkey. \\ gvural@cu.edu.tr, ORCID: 0000-0002-1385-7551
}

Date Received: May 17, 2020

Date Accepted: August 21, 2020

\section{To cite this document}

Hailu, S.M., Vural, G., (2020). Testing the weak form market efficiency of Borsa Istanbul: An empirical evidence from Turkish banking sector stocks. Journal of Economics, Finance and Accounting (JEFA), V.7(3), p.236-249.

Permanent link to this document: http://doi.org/10.17261/Pressacademia.2020.1291

Copyright: Published by PressAcademia and limited licensed re-use rights only.

\begin{abstract}
Purpose- The purpose of this study is to assess the weak form efficiency of Borsa Istanbul banking sector stocks using bank stocks listed in BIST 30. In addition to individual banking sector stocks, BIST 100 and BIST BANKS indexes are also investigated.

Methodology- For this purpose, weekly adjusted closing prices of selected stocks and indexes are collected from finance.yahoo.com and investing.com. The study period covers from January 4, 2010, to December 20, 2019. Therefore, a total of 520 observations for each stock and index are analyzed using autocorrelation, run test and unit root tests such as Augmented Dickey-Fuller (ADF), Phillips-Perron test (PP) and Kwiatkowski-Phillips Schmidt-Shin (KPSS).

Findings- The autocorrelation test results indicated that only VAKBAN and YAKBNK are efficient at the weak form of efficiency during the study period. On the other hand, the runs test result showed that only AKBANK and GARAN do not follow the random walk hypothesis and the other six samples are efficient at the weak form of efficiency. Finally, the unit root tests such as ADF, PP and KPSS results indicated that all samples do not follow the random walk hypothesis and they are not efficient at the weak form of market efficiency. BIST 100 and BIST BANKS indexes are inefficient according to all methods except in run test analysis.

Conclusion- Consequently, the three types of tests employed in this study exhibited a controversial result and it is difficult to give a general conclusion regarding the efficiency of the BIST Banking sector in the weak form. This indicated the probability of making an abnormal return by examining the Borsa Istanbul banking sector stocks' historical prices.
\end{abstract}

Keywords: Autocorrelation, banking sector, Borsa Istanbul, efficiency, run test, unit root tests JEL Codes: G10, G11, G14

\section{INTRODUCTION}

The relationship between capital markets and economic growth is one of the fields that catch the attention of economics and finance researchers. Several studies identified that there is an association between capital market development and economic growth. Carp (2012) states that stock markets have a vital role in the global economy, and their impacts on economic growth can be transferred to the real sector via their inevitable ways such as creating liquidity, market capitalization, risk distribution and allocation. Stock markets are also having an important function for the economy by providing liquidity to the market, creating fund sources through encouraging saving, expanding the ownership structure of capital for broadening society and playing as an economic indicator. The above-mentioned roles will effective when the stock market is efficient. The efficiency of the stock market is depending on the fairly and effectively change of securities' price in the market, fast and uninterrupted flow of information through the market, the low transaction cost in the market and the act of investors in the market rationally (Aydin, Başar \& Coşkun, 2015).

There are three forms of market efficiency such as allocational market efficiency, operational market efficiency and informational market efficiency (Bauer, 2004). Allocational market efficiency is concerned with how scarce resources are distributed fairly through capital market instruments. On the other hand, operational market efficiency implied that if a 
market is operationally efficient, market participants can perform their financial transaction at a possible minimum cost. According to the concept of informational market efficiency, if a market is informationally efficient, the market prices of financial instruments are reflected all available information (Pilbeam, 2018). This study concerned with only informational market efficiency and the phrase market efficiency is used as a proxy informationally efficiency through this paper.

The concept of the Efficient Market Hypothesis (EMH) depends on the random walk theory. In 1953, Maurice Kendall, a professor of statistics at the London School of Economics published an article named "The Analysis of Economic Time Series" in Journal of the Royal Statistical Society. He examined the weekly and monthly data for 22 economic series; 19 stock groups for the period from 1928 to 1938, monthly average price of wheat in the Chicago commodity markets from 1883 to 1934 , monthly average price of wheat from 1983 to 1934 (excluding 1915 to 1920) and monthly spot cotton at New York commodity markets from1816 to 1951 (excluding 1861-1866 and 1914-1920). The result of Kendall's study confirmed that the series' prices are following random changes from one term to the next (Kendall, 1953). Kendall's empirical examinations commonly named the "random walk theory" (Dimson \& Mussavian, 1998).

The EMH commenced in the 1960s by the works of Fama (1965) and Samuelson (1965). Fama (1965) indicates that the prices of stock markets follow a random walk and he defined efficient market as "a market where there are large numbers of rational, profit-maximizers actively competing, with each trying to predict future market values of individual securities, and where important current information is almost freely available to all participants." Samuelson (1965) states that in the reasonable market, price "perform a random walk with no predictable bias." According to Kendall (1953), the prices of stocks are shows unpredictable movement and there is no relationship between historical prices and future prices.

Initially, the stock market efficiency divided into a weak and strong form of efficiency by Harry Roberts and then Fama (1970) categorized it into three forms such as the weak, semi-strong and strong form of market efficiency. Fama identified three forms of information sets i.e. historical price information, publicly available information and unpublic information or insiders' information. The historical price information is used to test the efficiency of the stock market in its weak form. Firm-specific publicly available information (dividend announcement, merger and acquisition, earning announcement, new security issue and stock split) and general macro publicly available information (interest rate, exchange rate, GDP, commodity prices, inflation and money supply) are used to test the efficiency of stock market at the semi-strong form and insiders' information is used to test the strong form of efficiency.

Since in the 1970s several pieces of research conducted to identify the efficiency level of stock markets around the world. Identifying the efficiency levels of the stock markets has a vital role for policymakers and investors (Cooray \& Wickremasinghe, 2007). The efficiency of the stock markets can be tested at a micro-level using single stock prices or macro-level using stock indexes. Researchers in economics and finance almost agreed on the efficiency of stock markets in developed countries at the weak form of efficiency. On the contrary, there is no agreement on the efficiency of developing countries stock market at the weak form of efficiency (Malkiel, 1989). Therefore, there is a need to test developing countries' stock markets in the weak form. In this regard, this paper aims to test the weak form efficiency of Borsa Istanbul using baking sector stocks.

\section{THE GENESIS OF CAPITAL MARKET IN TURKEY}

The origins of the structured capital market in Turkey dates back to the second half of the 19th century. During the Ottoman Empire, the first capital market is known as" Dersaadet Securities Exchange" was established in 1866. After the foundation of the Turkish Republic, a new law was issued to rearrange capital markets "istanbul Securities and Foreign Exchange Bourse" was established in 1929 (Batten, Fetherston \& Szilagyi, 2004).

In 1982, the "Capital Market Board" was established to form, amend and administer the Turkish security markets. The board was responsible for providing reliable information to the public, creating a suitable environment for the operation of the market, taking necessary action to expand the share market, doing audits and examinations. Consequently, the Board started to prepare a suitable legal and institutional framework for Turkey's capital market and on October 19, 1984, a new "Capital Market Law" regarding the establishment capital market was decreed. The new stock market regulations enacted on December 18, 1985 consists of the rules and regulations of the stock exchange. On December 26, 1985, Turkey's new stock exchange officially inaugurated with the new name of "Istanbul Stock Exchange" (Chambers, 2006).

Until 2013, the Istanbul Stock Exchange sustained its operations in the capital market as a state-owned entity and showed a progressive in corresponding with the Turkish economy growth. In 2013, depending on the new "Capital Market Law" enacted, the three separate exchanges such as Istanbul Stock Exchange (IMKB), Istanbul Gold Exchange (IGE) and Turkish Derivatives Exchange (TurkDEx) merged as one entity known as Borsa İstanbul (BIST). BIST became a profit-based joint-stock company since in 2013 (Canbaş \& Doğukanlı, 2017). 
Currently, BIST encompasses four different markets such as equity market (publicly traded corporations' stocks from different sectors are traded), debt securities market (organized market for both fixed income securities and repo-reverse repo dealings are traded), derivatives market (single stock futures and options, index futures and options, currency futures and options, precious metals, commodity and energy futures are traded) and precious metals and diamond Markets. (Borsa İstanbul, 2019). BIST calculates several market indexes for investors based on capitalization, sustainability, liquidity, established cities, technology, sector, corporate governance, dividend, initial public offering, etc. 354 stock indexes are calculating in BIST and 59 indexes out of 354 are calculated in real-time and the rest 259 are calculated once a session (Borsa İstanbul, 2019). According to the Public Disclosure Platform (PDP), there are 490companies listed in BIST.

Even several studies conducted to test the weak form efficiency of Borsa Istanbul; there is no consensus between researchers on its efficiency at the weak form. Most of the studies tested BIST efficiency using stock indexes. This study is trying to assess the efficiency of Borsa Istanbul using both indexes such as BIST 100 and BIST BANKS, and 6 banking sector individual stocks included in the BIST 30 index. The finance sector is playing a significant role in Turkish economy development. This sector is mainly dominated by the banking business. As stated by the Investment office of Turkey (2019), the banking business has a $70 \%$ share from the overall finance sector services. Furthermore, the banking sector also plays a substantial contribution to the development of Borsa Istanbul and it has a significant share in terms of market value and trading volume. Due to the above-mentioned reasons, the banking sector is selected to investigate the efficiency of Borsa Istanbul.

The rest of the paper is set out as follows: In the next section, we analyzed related literatures on the efficiency of Turkish Stock market. In Section 4, we describe the method applied and the data used to test the efficiency of the Turkish stock market. The empirical results are presented in Section 5. The summary and conclusions are presented in section 6 .

\section{LITERATURE REVIEW}

Studies like Stengos\& Panas (1992) and Khandoker, Siddik \& Azam (2011), assessed the efficiency of banking sector stocks for Athens Stock Exchange and Dhaka Stock Exchange respectively. This section devoted to reviewing empirical studies conducted to assess the efficiency of Istanbul security exchange (Borsa Istanbul). Several studies were done to test the efficiency of Borsa Istanbul using different methods which covered various study periods. These empirical studies reviewed by chronological order as follows.

Alparslan (1989) tested the efficiency of the Istanbul Stock Exchange (ISE) using the weekly prices of 11 selected individual stocks for the period covering from January 10, 1986 - October 28, 1988. To investigate the weak form of efficiency, he used autocorrelation, runs test and filter test. The outcome of autocorrelation and runs tests indicated that ISE was efficient at the weak form and based on filter tests result, ISE was not efficient at the weak form. Balaban (1995) investigated the efficiency of Istanbul Security Exchange (ISE) at the weak and semi-strong form of efficiency using autoregression and autocorrelation for a total 1,646 closing prices of İstanbul Securities Exchange Composite Index (ISECI) covering a period from January 4, 1988, to August 5, 1994. The finding indicates that the ISE was not efficient neither at the weak-form nor the semi-strong form efficiency.

To test whether Istanbul Stock Exchange (ISE) is following the random walk hypothesis or not, Buguk \& Brorsen (2003) did research using 396 observations enclosed from 1992 to 1999 for ISE industrial, composite and financial indexes weekly closing prices. They applied unit root testes (Augmented Dickey-Fuller test), GPH fractional integration test and variance ratio testes (LOMAC single variance ratio test and Rank- and sign-based variance ratio tests). According to ADF unit root, LOMAC variance ratio, and GPH fractional integration tests, the three indexes are following the random walk hypothesis and on the other hand the rank- and sign-based variance ratio tests indicated that the selected indexes are not following the random walk hypothesis.

Muslumov, Aras \& Kurtulus (2003) studied the weak form of efficient market hypothesis in ISE using the widest study period which covered from 1990 to 2002. They collected the weekly prices of ISE-100 index and individual stocks that included in ISE-100 index. Generalized Auto-regressive Conditional Heteroscedastic (GARCH) method is employed to test efficiency. The finding indicated that ISE-100 national index follows the weak form of efficient market hypothesis and $65 \%$ of the individual stocks studied do not show the weak form of efficient market hypothesis while the remaining $35 \%$ does.

Kiliç (2005) assessed the weak form of efficient market hypothesis for ISE National 100 index using Markov chain methodology for the period covering from September 23, 1987, to October 2, 2004. His finding indicates that ISE does hold the weak form of an efficient market hypothesis. Aga \& Kocaman (2008) investigated the efficiency levels of ISE by calculating their own index named "return index-20". They select the big 20 companies traded in ISE and calculated monthly return for the period covered from January 1986-November 2005. They analyze the collected data using time series regression method. Their finding indicated that ISE was efficient at the weak form of efficiency. 
Al-Jafari (2013) tested the randomness behaviour of ISE using XU 030 index daily prices from January 1997 to December 2011. He employed unit root tests, runs tests and variance ratio test to assess the efficiency form of ISE. His finding indicated that ISE does not efficient at the weak form of efficiency, means ISE does not follow the random walk hypothesis. Saymeh (2013) empirically investigated the weak form of efficiency for Amman Stock Exchange, (ASE) and Istanbul Security exchange (ISE). He collected historical price information for the period 2000-2011 and analyzed using Ljung Box Autocorrelation test, Runs test, Dickey-Fuller Unit Root test, and Individual Variance Ratio test. The result from run and Autocorrelation tests indicated that ISE does not follow the random walk hypothesis while Dickey-Fuller tests and Individual Variance Ratio tests show that it follows the random walk hypothesis.

Kapusuzoglu (2013) did research to assess the efficiency of ISE using 3943 daily price observations of ISE National 100 index for the period from 1996 t0 2012. He implemented unit root tests such as Augmented Dickey-Fuller (ADF) and Phillips-Perron (PP) tests to investigate the efficiency of ISE. The finding shows that the ISE National 100 index did not follow the weak form of an efficient market hypothesis. Daver, Karacaer \& Hülya (2013) examined the efficiency of Turkish Derivatives Exchange (TurkDEX 100) and Borsa Istanbul (BIST 100 Index) daily return for the period from December 2, 2007, to August 2, 2013, using serial correlation test, the runs test, and the variance ratio test. They conclude that ISE is efficient at the weak form of efficiency.

Gozbasi, Kucukkaplan \& Nazlioglu (2014) assessed the efficiency of Borsa Istanbul using the daily data for the Borsa Istanbul composite index (BIST 100), industry index, financial index and services index for the period from July 1, 2002, to July 7, 2012. The employed linearity test developed by Harvey et al. (2008 and the nonlinear Exponential Smooth Transition Autoregressive (ESTAR) unit root test developed by Kruse (2011). They conclude that Turkey's stock market is following the weak form of an efficient market hypothesis. Yücel, (2016) studied the efficiency of Borsa Istanbul by collecting the returns of 22 indexes for the period from 2000 to 2015. The analyze is conducted using unit root tests such as Augmented Dickey-Fuller (ADF) and Phillips-Perron (PP). The finding indicated that all 22 indexes examined in this study are efficient at the weak form of efficiency. Bulut (2016) tested the weak form of the efficient market hypothesis for BIST 100 index by using the monthly observations from January 2003 to September 2015. He employed Lee and Strazicich (2003) and Carrion-i-Silvestre et al. (2009) unit root tests. The finding shows that BIS 100 index is efficient at the weak form in this study period.

Akgün \& Şahin (2017) investigated the weak-form of efficiency for BIST indexes such as BIST 100, BIST Industry, BIST Service and BIST Financial index. They collected the daily closing prices of such indexes for the period between January 4, 2010November 2, 2017 and analyzed using unit root tests (Augmented Dickey-Fuller (ADF), Phillips-Perron (PP) and KwiatkowskiPhillips Schmidt-Shin (KPSS)) and structural broken unit root tests. The finding indicated that BIST is inefficient at the weak form of efficiency. Tas \& Atac (2019) investigated the randomness of Borsa Istanbul using Dickey-Fuller and Runs test for separate two study periods. BIST30 index and companies included in BIST 30 index daily prices collected for a five-year period from 2013 to 2018. And also, daily prices for indexes such as BIST30, BIST100 and BISTTUM are analyzed for the period from 2000 to 2018. The finding implies that the analyzed indexes are efficient at the weak form according to the Dickey-Fuller test while they are not efficient according to the run test.

Aliyev (2019) tested the weak form efficiency of Borsa Istanbul using BIST 100 indexes weekly price covering the period from 2000 to 2014. To analyze the efficiency, Smooth transition autoregressive (STAR) type nonlinear model is employed. According to Aliyev's nonlinear analysis, BIST is inefficient at the weak form of efficiency.

To sum up, 16 studies conducted to test the weak form of efficient market hypothesis in Borsa Istanbul are reviewed. These studies employed different analyzing methods, study periods and data. Some papers analyzed the efficiency based on individual companies' stock and some of the analyzed using stock indexes. About half of the papers reviewed concluded that Borsa Istanbul is efficient at the weak form and the rest half concluded that BIST is not efficient at the weak form of efficiency. There are also some different results in the same study used different models. Some models support the efficiency and some do not support. The inferences we can take from the previous studies are there is not a common agreement on the efficiency of BIST at the weak form and there is a need for more studies regarding the efficiency of BIST. In this regard, this study aims to investigate the sectoral efficiency of BIST using the banking sector index and banking sector individual stocks.

\section{DATA AND METHODOLOGY}

As clearly illustrated in the introduction part of this paper, Fama (1970) identified three types of information sets to test the efficiency of stock markets. Among these information sets, historical price information is used to test the market efficiency at its weak form. Therefore, it is possible to test the weak form of efficiency using daily, weekly and monthly historical price observations of the stock. According to the weak form of an efficient market hypothesis, if a market is efficient at the weak form it is impossible to predict the future prices of securities. There should be no relationship between past prices and future prices. Therefore, prices should be changed randomly. In other word, prices should follow the random walk hypothesis. 
There are different statistical methods to test the randomness of time series variables. These methods are classified into parameter and none parameter tests. In most of the literature, parameter testes like unit root tests including Augmented Dickey-Fuller (ADF), Phillips-Perron test (PP) and Kwiatkowski-Phillips Schmidt-Shin (KPSS) have been extensively employed (Palachy,2019). On the other hand, nonparametric testes such as autocorrelation, run test and Markov chains test have been used to test randomness (Dufour, Lepage, \& Zeidan, 1982).

After reviewing studies conducted in the similar area of this study, autocorrelation, run test and unit root tests such as Augmented Dickey-Fuller (ADF), Phillips-Perron test (PP) and Kwiatkowski-Phillips Schmidt-Shin (KPSS) selected to analyze the randomness of Borsa Istanbul using 2 indexes and 6 banking sector individual stocks.

\subsection{Autocorrelation}

According to BusinessDictionary.com, Autocorrelation defined as "a situation in which a time series data is influenced by its own historical values". Tintner (1965) describes autocorrelation as "lag correlation of a given series with itself, lagged by a number of time units", where he used the term serial correlation to "lag correlation between two different series.

The autocorrelation of a series $x$ at lag $k$ is calculated as:

$A C_{K}=\frac{\sum_{t=k+1}^{T}\left(x_{t}-\bar{x}\right)\left(x_{t-k}-\bar{x}\right)}{\sum_{t=1}^{T}\left(x_{t}-\bar{x}\right)^{2}}$

Where: $A C_{K}$ is the autocorrelation coefficient of series at lag $k$ and $\bar{x}$ is the sample mean of $x$. If $A C_{1}$ is nonzero, it indicated that the sequences are serially correlated at first order. If an autocorrelation coefficient is outside the border calculated as the approximate of two standard error, it is significantly different from zero at and it also significant at the $5 \%$ significance level (Eviews.com, 2019).

\subsection{The Runs Test}

The runs test, it is also known as a Wald-Wolfowitz runs test is one of the popular nonparametric tests employed to detect a nonrandom pattern in a time series data. For instance, in a time series that have two or more types of signs, a run is described as a sequence of one or more similar signs which are followed and headed by separate signs. The run test depends on the extent of similar runs (Wang, 2003). For significant samples, we should to calculate a $z$-score and using the normal distribution table it is possible to find the critical value of $z$-scores. To calculate the Z-score of the run test for sizable samples, we can use the following formulas:

$\bar{x} R=\frac{2 n_{1} n_{2}}{n_{1}+n_{2}}+1$

Where $\bar{x} R$ the mean value of runs is, $n_{1}$ is the number of records the first occasion happened, and $n_{2}$ is the amount of records the second occasion happened;

Where $S_{R}$ is the standard deviation of runs;

$Z^{*}=\frac{R+h-\bar{x} R}{S_{R}}$

Where $z^{*}$ is the $z$-score for a normal estimate of the data, $R$ is the quantity of runs, and $h$ is the correction for continuity, \pm 0.5 ,

Where;

$h=+0.5$ if $R<\left(2 n_{1} n_{2} /\left(n_{1}+n_{2}-1\right)+1\right.$

$h=-0.5$ if $R>\left(2 n_{1} n_{2} /\left(n_{1}+n_{2}-1\right)+1\right.$

To test the randomness of the sample stock price series, we can construct the hypothesis as follows:

$H_{0}$ : The series of stock prices are changed randomly.

$H_{1}$ : The series of stock prices are not changed randomly.

Therefore, the decision rule is not rejecting the null hypothesis when the $z$-score $\left(Z^{*}\right)$ value is between $\mathbf{- 1 . 9 6}$ and $+\mathbf{1 . 9 6}$ at 5\% level of significance level (Corder, \& Foreman, 2014). 


\subsection{Unit Root Tests}

In a unit root test, the null hypothesis can be stated as "a time series contains a unit root" whereas the alternative hypothesis can be expressed as "a time series is stationary" (Harvey, 2005). The existence of a unit root in a time series indicates that a series is non-stationery. One of the ordinary examples of none stationary is the random walk hypothesis (Nkoro \& Uko, 2016). Consequently, we can test the randomness of historical stock prices through unit root tests.

Unit root test is a common type of parametric tests used to test the stationarity or non-stationarity of a time series. Augmented Dickey-Fuller (ADF), Phillips-Perron (PP) and Kwiatkowski-Phillips Schmidt-Shin (KPSS) tests are the most frequently applied unit root tests (Arltová \&Fedorová,2016).

The basic test for unit root is Augmented Dickey-Fuller (ADF). According to ADF, the null hypothesis is stated as a time series are following the random walk. The ADF model can be statistically defined as follows (Sjö, 2008).

$\Delta x_{t}=\alpha_{0}+\beta_{t}+\pi x_{t-1}+\sum_{i=}^{k} \alpha_{i} \Delta x_{t-i}+\varepsilon_{t}$

Where; $\Delta$ represents first differences, $\varepsilon_{t}$ is the random error term which is normally distributed with a mean of zero and $x_{i}$ is the log of the price, $\pi$ is the autoregression parameter and $k$ is the lagged values of $\Delta x$. Determining the number of lag is very important. In this study, Akaike Information Criterion (AIC) is used to decide the number of lags. If $H_{0}: \pi=0$, the series holds a unit root and hence it is non-stationary. We can say also the series is integrated at the first order I (1). If $H_{1}: \pi<0$, the series does not have a unit root and it is called stationary. In this case, the series is integrated at I (0) (Arltová \&Fedorová, 2016).

Phillips-Perron (PP) unit root test is a non-parametric adjustment to the basic Dickey-Fuller test. In the non-stationary test of time series data produced through the serial correlated and heteroscedastic unsystematic element, it is repeatedly a problem regarding the choice of lag $k$ in the model. Phillips and Perron (1988) solved this problem by modifying the basic Dickey-Fuller test as a non-parametric test without the addition of lagged variation terms (Virmani, 2004; Gujarati, 2009).

In contrary with ADF and PP tests, the complementary unit root model launched in 1992 by Kwiatkowski, Phillips, Schmidt and Shin, and known as KPSS test. It assumes that the null hypothesis is the stationarity of the series and the alternative hypothesis is the non-stationarity or the presence of unit root in the series (Syczewska, 2010).

\subsection{The Sample and Data}

To test the efficiency of BIST in banking sector, six bank stocks listed in BIST such as Ak Bank (AKBNK.IS), Turkey Garanti Bank (GARAN.IS), Turkey Halk Bank (HALKB.IS), Turkey Is Bank (ISCTR.IS), Turkey Vakiflar Bank (VAKBN.IS) and Yapi \& Kredi Bank (YKBNK.IS) are selected. The main criterion to select individual banks is to be included in the BIST 30 index. The aforementioned six banks are included in the BIST 30 index. In addition to individual banking sector stocks, BIST 100 and BIST BANKS indexes are also selected.

After identifying the sample individual stocks and indexes, the next decision is regarding data source and study period. In this regard, the weekly adjusted closing prices of selected stocks and indexes are collected from finance.yahoo.com and investing.com. The study period covers from January 4,210 to December 20, 2019. Therefore, a total of 520 observations for each stock and index is analyzed. The weekly observation for ISCTR is found starting from February 15, 2010, and a total of 514 weekly observations analyzed. Graphical description of the data series which selected to test the efficiency of BIST banking sector efficiency is presented in figure 1 and figure 2 below.

Following studies such as Fama (1965); Solnik (1973); Praetz (1980); Cooper (1982); Parkinson (1984a) and Dickinson \& Muragu (1994), the collected weekly prices are converted into a natural logarithm. And then the difference between consecutive log prices are calculated as follows:

$D_{T}=\log P_{t}-\log P_{T-1}$

Where; $D_{t}$ is the difference in log prices from time $t-1$ to time $t$ and $P_{t}$ is an adjusted weekly closing prices of selected stocks for the study. In place of using price changes, logarithm price changes are more appropriate to detect the randomness of series. Normal price changes for a particular share is a function of an increasing trend of the share while using logs is more neutralize from this effect. In the case of run test, there is no difference between the simple and log price changes due to run test concerned with only to the sign of the change, not the amount (Panas, 1990). 
Figure 1: BIST 100 and BIST BANKS Indexes Historical Prices in Turkish Lira (TL)

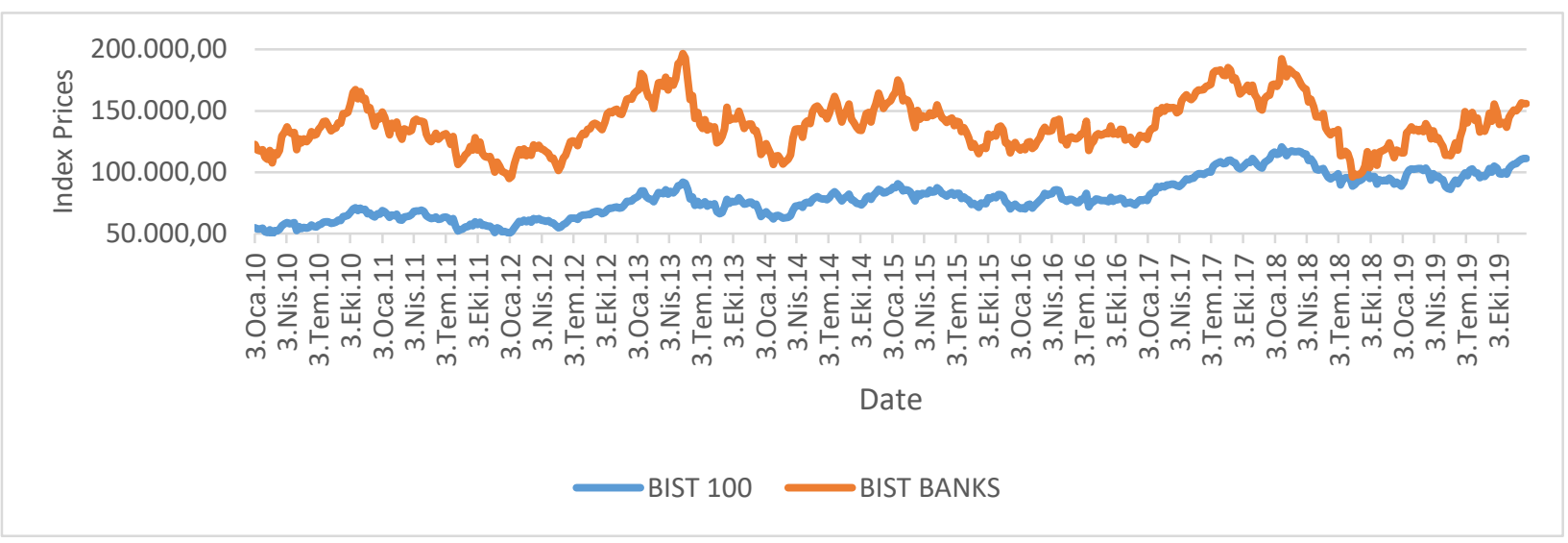

Figure 2: Selected Banks Historical Stock Prices in Turkish Lira (TL)

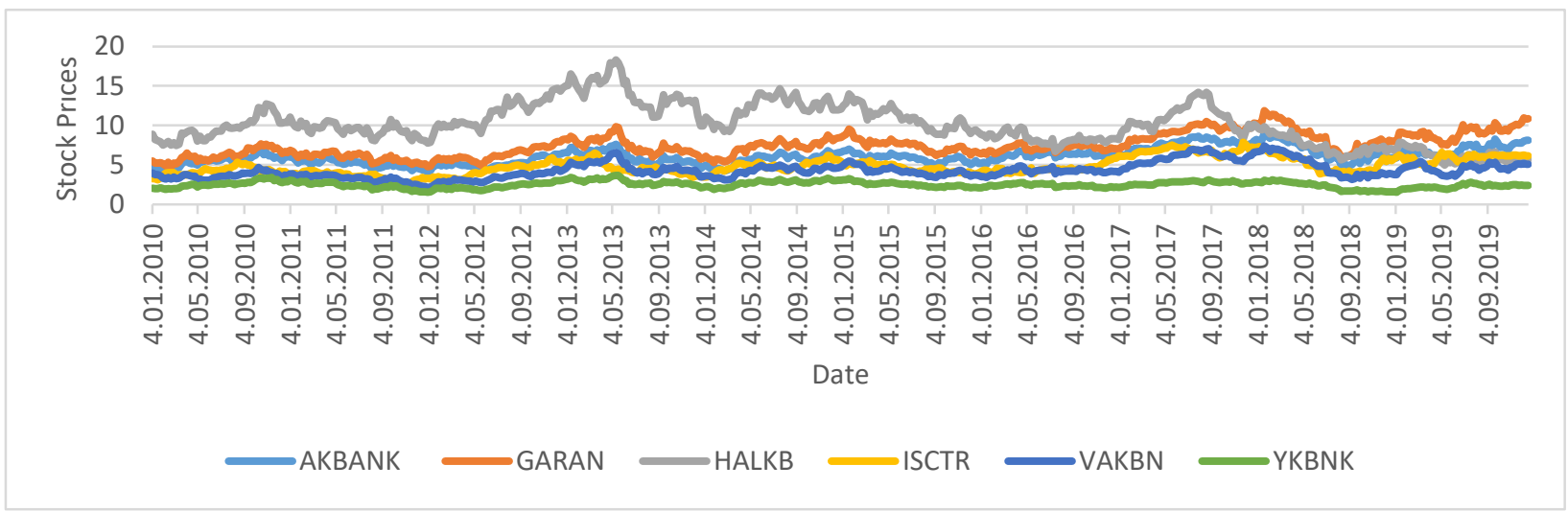

\section{EMPIRICAL RESULTS}

In this section the descriptive properties of the series and selected analyzing methods such as autocorrelation, run test and unit root test results are summarized.

\subsection{Descriptive Statistics}

One of the basic assumptions of the efficient market hypothesis is the randomness of the series, meaning that the series should follow the random walk hypothesis. If a series is following a random walk, it should be normally distributed. The descriptive statistics which shows the normality of the selected series is presented in table 1 . The descriptive statistics which summarized in table 1 indicated that the samples' data are not normally distributed. The $p$ values of all series are less than $5 \%$. This means the normal distribution of the null hypothesis is not accepted. If the series is exactly normally distributed, the skewness and Kurtosis coefficient will be zero. In the case of this study, all 8 stock and index price change series' skewness and Kurtosis coefficients are different from zero. All series are negatively skewed. Normally distribution is one of the criteria for the randomness of a series. From the perspective of these descriptive statistics, all series are inefficient.

Table 1: Descriptive Statistics of Weekly Log Index and Stock Price Changes

\begin{tabular}{lrrrrrrrr}
\hline & BIST_100 & \multicolumn{1}{c}{ BIST_BANK } & \multicolumn{1}{c}{ AKBANK } & \multicolumn{1}{l}{ HALKB } & \multicolumn{1}{l}{ ISCTR } & VKBAN & \multicolumn{1}{l}{ YKBNK } & GARAN \\
\hline Mean & 0.0014 & 0.0005 & 0.0010 & -0.0009 & 0.0012 & 0.0005 & 0.0003 & 0.0013 \\
\hline Median & 0.0030 & 0.0037 & 0.0023 & 0.0000 & 0.0033 & 0.0023 & 0.0029 & 0.0030 \\
\hline Maximum & 0.0834 & 0.1326 & 0.1263 & 0.1686 & 0.1804 & 0.1548 & 0.1551 & 0.1611 \\
\hline
\end{tabular}




\begin{tabular}{lrrrrrrrr}
\hline Minimum & -0.1437 & -0.1845 & -0.1814 & -0.2197 & -0.1618 & -0.2098 & -0.2225 & -0.2147 \\
\hline Std. Dev. & 0.0310 & 0.0433 & 0.0463 & 0.0529 & 0.0442 & 0.0511 & 0.0475 & 0.0474 \\
\hline Skewness & -0.6142 & -0.3230 & -0.2936 & -0.1330 & -0.1969 & -0.2851 & -0.4481 & -0.2605 \\
\hline Kurtosis & 4.2852 & 4.1361 & 3.8705 & 3.7748 & 3.8363 & 4.2491 & 4.4483 & 4.4124 \\
\hline Probability & 0.000 & 0.0000 & 0.0000 & 0.0007 & 0.0003 & 0.0000 & 0.0000 & 0.0000 \\
\hline Observations & 520 & 520 & 520 & 520 & 514 & 520 & 520 & 520 \\
\hline
\end{tabular}

\subsection{Correlation between Selected Samples}

The correlation coefficient between series shows whether the log price changes of selected stocks and indexes are move together or not. In this context, the correlation coefficients between them are presented in Table 2. All individual bank stocks are highly correlated with the BIST 100 and BIST BANKS indexes. All single bank stocks are also highly correlated with each other. The minimum correlation coefficient of 0.742 . Therefore, it is not recommended diversifying investment only in banking sectors stocks. It also indicates most of the banks are affected similarly by the event happened in the markets.

Table 2: Correlation Matrix between the Sample Bank Stocks, BIST 100 and BIST 100 Indexes

\begin{tabular}{l|llllllll}
\hline \multicolumn{1}{l}{} & BIST 100 & BIST BANK & AKBANK & GARAN & HALKB & ISCTR & VKBAN & YKBNK \\
\hline BIST 100 & 1.000 & & & & & & & \\
BIST BANK & 0.937 & 1.000 & & & & & \\
AKBANK & 0.854 & 0.932 & 1.000 & & & & & \\
GARAN & 0.870 & 0.953 & 0.860 & 1.000 & & & & \\
HALKB & 0.830 & 0.859 & 0.763 & 0.774 & 1.000 & & & \\
ISCTR & 0.833 & 0.884 & 0.788 & 0.821 & 0.742 & 1.000 & \\
VKBAN & 0.860 & 0.900 & 0.803 & 0.833 & 0.812 & 0.811 & 1.000 \\
YKBNK & 0.851 & 0.883 & 0.783 & 0.826 & 0.752 & 0.818 & 0.831 \\
\hline
\end{tabular}

\section{3. Autocorrelation Analysis}

In this study, autocorrelation analysis used to identify the randomness of log price changes of selected indexes and stock prices. For all samples, serial correlation is employed for lag 1 to 30 . The autocorrelation coefficients for all samples with 30 lags are presented in table 3. The results also presented graphically for each sample from chart 1 to chart 8 . The null hypothesis of serial correlation states that there is no serial correlation between series.

The estimated two standard error boundaries calculated as \pm 0.0439 . As the observation of ISCTR is less than other samples, the estimated standard error is estimated as \pm 0.0441 if the autocorrelation coefficient is larger than two standard error sums, the series is significantly non-zero and indicated the existence of serial correlation. The autocorrelation coefficient which greater than two standard error are bolded in the table and colored red in the autocorrelation chart.

Out of 2 indexes and 6 individual stocks analyzed in this study, 2 indexes and 4 stocks have at least one significant autocorrelation. In the case of BIST 100, lag 14 and lag 29 are significantly autocorrelated. BIST BANKS index has significant autocorrelations at lag 1, 14 and 19. In the case of individual bank stocks such as AKBAK, GARAN, HALKB and ISCTR have at least one autocorrelation. AKBAK and GARAN are significantly autocorrelated at lag 1 and lag 19. On the other hand, ISCTR log first difference is autocorrelated at lag 14. In contrary, VAKBAN and YAKBNK do not have any significant serial correlations. Depending on autocorrelation analysis, BIST banking sector is not efficient at the weak form of efficient level. 
Table 3: Results of Autocorrelation Test

\begin{tabular}{|c|c|c|c|c|c|c|c|c|}
\hline Lag & BIST 100 & BIST BANK & AKBANK & GARAN & HALKBN & ISCTR & VKBAN & YKBANK \\
\hline 1 & -0.077 & -0.112 & -0.126 & -0.176 & -0.051 & -0.038 & -0.048 & -0.085 \\
\hline 2 & 0.052 & 0.042 & -0.011 & 0.055 & -0.049 & 0.070 & 0.077 & 0.046 \\
\hline 3 & -0.030 & -0.012 & 0.012 & -0.009 & -0.003 & -0.061 & 0.024 & -0.008 \\
\hline 4 & -0.033 & -0.018 & -0.060 & -0.038 & -0.009 & 0.042 & -0.017 & 0.048 \\
\hline 5 & 0.022 & 0.041 & 0.034 & 0.054 & -0.015 & 0.053 & 0.025 & -0.026 \\
\hline 6 & -0.043 & -0.060 & -0.065 & -0.078 & 0.012 & -0.021 & -0.012 & -0.054 \\
\hline 7 & 0.022 & 0.049 & 0.082 & 0.027 & -0.010 & 0.037 & 0.016 & 0.011 \\
\hline 8 & -0.046 & -0.042 & -0.085 & 0.000 & -0.046 & -0.003 & -0.041 & 0.004 \\
\hline 9 & -0.050 & -0.033 & -0.008 & -0.040 & -0.023 & -0.050 & -0.031 & -0.055 \\
\hline 10 & -0.031 & -0.039 & -0.032 & -0.041 & -0.006 & -0.085 & -0.064 & -0.039 \\
\hline 11 & 0.030 & 0.033 & 0.035 & 0.031 & 0.021 & 0.061 & -0.007 & 0.063 \\
\hline 12 & 0.040 & 0.038 & 0.023 & 0.028 & 0.059 & 0.019 & 0.052 & 0.013 \\
\hline 13 & -0.014 & -0.033 & -0.017 & -0.043 & -0.025 & 0.013 & -0.041 & -0.007 \\
\hline 14 & -0.113 & -0.092 & -0.064 & -0.063 & -0.135 & -0.100 & -0.074 & -0.062 \\
\hline 15 & -0.047 & -0.049 & -0.047 & -0.058 & -0.030 & -0.043 & -0.056 & -0.017 \\
\hline 16 & -0.029 & 0.017 & 0.038 & 0.035 & -0.010 & 0.059 & -0.056 & -0.047 \\
\hline 17 & 0.025 & 0.025 & 0.007 & 0.014 & 0.012 & -0.004 & 0.024 & 0.050 \\
\hline 18 & 0.040 & 0.063 & 0.054 & 0.049 & 0.060 & 0.025 & 0.039 & 0.041 \\
\hline 19 & -0.048 & -0.093 & -0.115 & -0.090 & -0.040 & -0.087 & -0.032 & 0.037 \\
\hline 20 & 0.007 & 0.017 & 0.002 & 0.052 & -0.046 & 0.060 & -0.005 & 0.006 \\
\hline 21 & 0.046 & 0.017 & 0.006 & -0.007 & 0.021 & 0.003 & 0.004 & 0.032 \\
\hline 22 & 0.064 & 0.077 & 0.061 & 0.052 & 0.089 & 0.066 & 0.072 & 0.071 \\
\hline 23 & 0.050 & 0.035 & 0.022 & 0.032 & 0.016 & 0.002 & 0.032 & -0.009 \\
\hline 24 & 0.005 & -0.035 & -0.049 & -0.039 & -0.003 & 0.009 & -0.007 & 0.021 \\
\hline 25 & 0.017 & 0.015 & 0.049 & -0.009 & 0.004 & -0.031 & -0.018 & -0.047 \\
\hline 26 & 0.022 & -0.001 & -0.006 & -0.002 & 0.069 & 0.032 & -0.007 & 0.054 \\
\hline 27 & 0.024 & 0.028 & 0.034 & 0.027 & 0.003 & 0.026 & 0.029 & -0.021 \\
\hline 28 & 0.054 & 0.019 & 0.002 & 0.035 & 0.006 & 0.006 & 0.013 & -0.009 \\
\hline 29 & 0.089 & 0.063 & 0.057 & 0.050 & 0.055 & 0.046 & 0.045 & 0.069 \\
\hline 30 & -0.042 & -0.034 & -0.028 & -0.029 & -0.035 & -0.054 & -0.027 & 0.001 \\
\hline
\end{tabular}



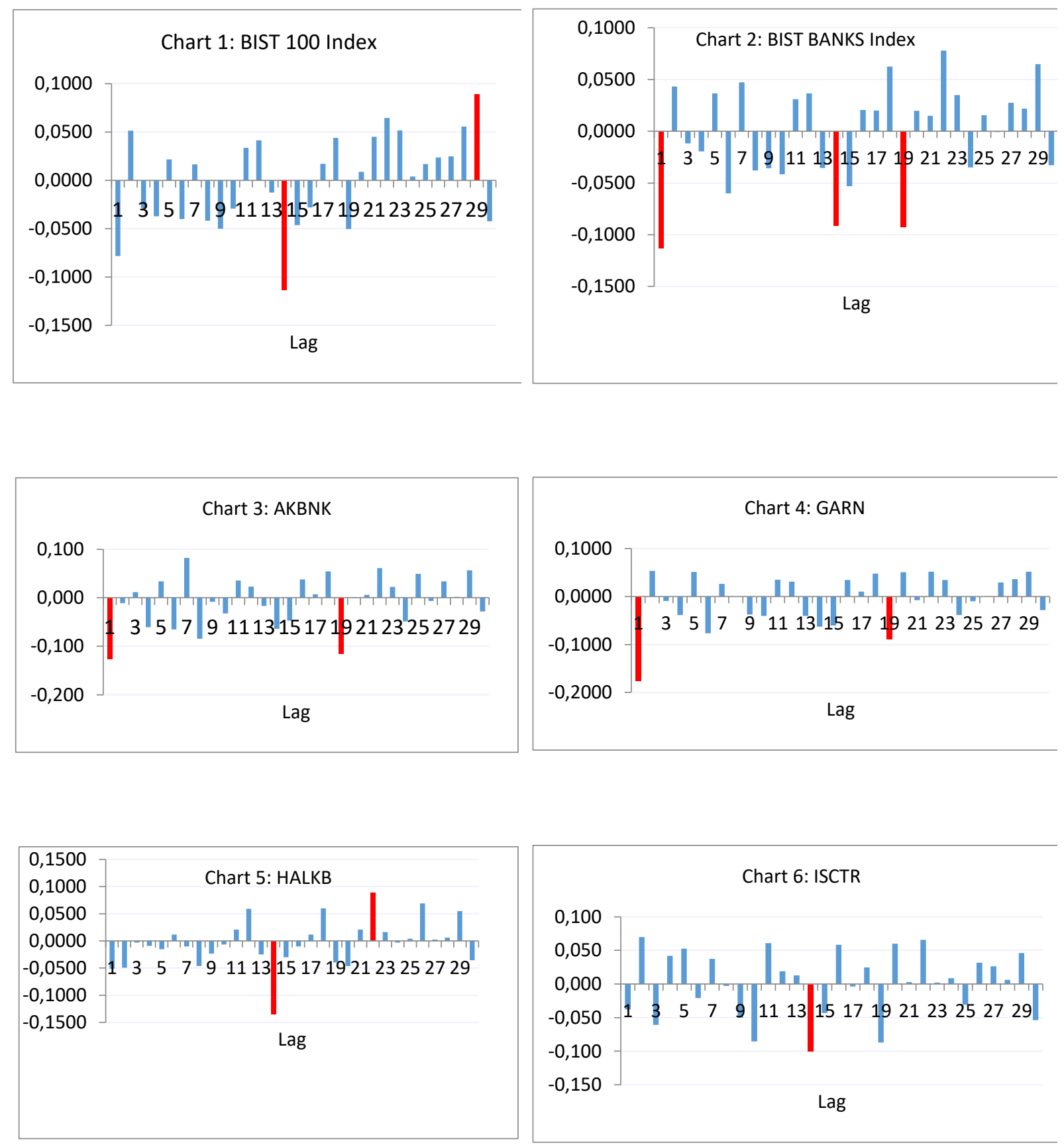


\subsection{Analysis of Runs Tests}

The run-tests are conducted for selected 8 series and, the result is presented in Table 4. To decide whether the samples' series are following a random walk or not z-value and p-value is important. As stated previously in the methodology part, if the $z$-value is between -1.96 and +1.96 , the randomness of the null hypothesis is accepted at a $5 \%$ level of the significance level. In this regard, only AKBANK and GARAN stocks log return series has a z-values more than the stated boundaries and they are not following the random walk. According to this test, the rest 6 series does follow the random walk hypothesis.

On the other hand, $p$-value also used to decide the randomness of the series. If the $p$-value is less than $5 \%(P$-value $\leq \alpha)$, we can reject the null hypothesis of randomness. In this concern, the $p$-values of all series except AKBANK and GARAN are too high and more than 5\%. Depending on p-value coefficients, only AKBANK and GARAN does not follow the random walk hypothesis.

In general, the run test results such as z- value and p-vale indicated that only two series out of eight does not follow the random walk hypothesis. Depending on run tests, the sample series selected for this study representing the banking sector of BIST does follow the random walk hypothesis except AKBANK and GARAN. Therefore, in light of the runs test, BIST banking sector stock is efficient at the weak form of efficiency.

Table 4: Run Test Results for Weekly Log Returns of Sample Indexes and Stocks

\begin{tabular}{lllllllll}
\hline & BIST 100 & BIST BANKS & AKBANK & GARAN & HALKB & ISCTR & VAKBN & YKBNK \\
\hline \# of non-missing obs & 520 & 520 & 520 & 520 & 520 & 514 & 520 & 520 \\
\hline \# below mean & 246 & 241 & 252 & 250 & 257 & 248 & 254 & 253 \\
\hline \# on or above mean & 274 & 279 & 268 & 270 & 263 & 266 & 266 & 267 \\
\hline \# of runs & 271 & 271 & 287 & 286 & 262 & 262 & 260 & 270 \\
\hline E(R) & 260.246 & 259.612 & 260.754 & 260.615 & 260.965 & 257.685 & 260.862 & 260.812 \\
\hline Stdev(R) & 11.358 & 11.330 & 11.380 & 11.374 & 11.389 & 11.311 & 11.385 & 11.382 \\
\hline z-value & 0.947 & 1.005 & $\mathbf{2 . 3 0 6}$ & $\mathbf{2 . 2 3 2}$ & 0.091 & 0.382 & -0.076 & 0.807 \\
\hline p-value (2-tailed) & 0.344 & 0.315 & $\mathbf{0 . 0 2 1}$ & $\mathbf{0 . 0 2 6}$ & 0.928 & 0.703 & 0.940 & 0.420 \\
\hline
\end{tabular}

\subsection{The Unit Root Tests}

Three types of unit root tests such as ADF, PP and KPSS tests are employed to assess the randomness of selected series. The test equation that include the constant applied for all testes. The test conducted for all samples at the level I (0) and 1 st difference I (1). The three types of unit root test results are summarized in Table 5 below.

Table 5: Unit Root Tests Results

\begin{tabular}{|c|c|c|c|c|c|c|}
\hline \multirow[t]{2}{*}{ Samples } & \multicolumn{2}{|c|}{ ADF } & \multicolumn{2}{|c|}{ PP } & \multicolumn{2}{|c|}{ KPSS } \\
\hline & $\mathrm{I}(0)$ & I (1) & $\mathrm{I}(0)$ & I (1) & $\mathrm{I}(0)$ & I (1) \\
\hline BIST 100 & -1.68 & $-24.58^{*}$ & -1.68 & $-24.58^{*}$ & $2.45^{*}$ & 0.02 \\
\hline BIST BANKS & $-3.15^{* *}$ & $-25.47^{*}$ & $-3.41 * *$ & $-25.54^{*}$ & 0.18 & 0.03 \\
\hline AKBANK & -2.71 & $-25.81^{*}$ & -2.81 & $-25.96^{*}$ & $1.50 *$ & 0.03 \\
\hline GARAN & -2.28 & $-27.18^{*}$ & -2.44 & $-27.13^{*}$ & $1.81^{*}$ & 0.03 \\
\hline HALKB & -1.83 & $-23.98^{*}$ & -1.68 & $-24.09 *$ & $1.13^{*}$ & 0.13 \\
\hline ISCTR & -2.46 & $-15.17^{*}$ & -2.57 & $-23.48^{*}$ & $1.32 *$ & 0.03 \\
\hline VAKBNK & -2.61 & $-15.26^{*}$ & -2.65 & $-23.66^{*}$ & $1.16^{*}$ & 0.03 \\
\hline YKBNK & $-3.23 * *$ & $-24.76^{*}$ & $-3.26 * *$ & $-24.72^{*}$ & 0.16 & 0.04 \\
\hline \multicolumn{7}{|c|}{$\begin{array}{l}\text { Notes: Test equations that include a constant is employed in all cases. } \\
\text { Decision criteria of critical value for the ADF and PP tests in case of constant test equation are: }-3.44(1 \%) ;-2.87(5 \%) \text { and }-2.57 \\
\text { (10\%). } \\
\text { - Decision criteria of critical value for the KPSS tests in case of constant test equation are: } 0.74(1 \%) ; 0.46(5 \%) \text { and } 0.35(10 \%) \text {. } \\
\text { - } *, * * \text {, represent significant at } 1 \% \text {, and } 5 \% \text {, respectively. }\end{array}$} \\
\hline
\end{tabular}

At level, ADF and PP test statistics for BIST BANKS and YKBNK have rejected the null hypothesis of a unit root (non-stationary) at $5 \%$ significance level and accepted the null hypothesis for the other six samples. Therefore, except BIST BANKS and YKBNK, 
all samples have a unit root, meaning that they are non-stationery. Non-stationarity is one of the characteristics of the random walk. Accordingly, it can be concluded that BIST 100, AKBNK, GARAN, HALKB, ISCTR and VAKBNK are efficient at the weak form of efficiency at the level. This conclusion also supported by KPSS results.

At weekly difference, ADF and PP unit root test results rejected the null hypothesis of a unit root (non-stationary) at $1 \%$ significance level. Therefore, there is no evidence for the efficiency of the 8 samples analyzed in this study. The inefficiency of the series investigated by ADF and PP also supported by KPSS test results. In general, according to unit test results, BIST 100 , BIST BANKS indexes and 6 individual bank stocks analyzed in this study are not efficient at the weak form of market efficiency. The finding of this study is strength the conclusion of the latest study conducted by Tas \& Atac (2019).

\section{SUMMARY AND CONCLUSION}

The aim of this study is assessing the efficiency of Borsa Istanbul banking sector stocks. To test the efficiency of BIST in banking sector, six bank stocks listed in BIST such as Ak Bank (AKBNK.IS), Turkey Garanti Bank (GARAN.IS), Turkey Halk Bank (HALKB.IS), Turkey Is Bank (ISCTR.IS), Turkey Vakiflar Bank (VAKBN.IS) and Yapi \& Kredi Bank (YKBNK.IS) are selected. The main criteria to select individual banks is to be included in the BIST 30 index. In addition to individual banking sector stocks, BIST 100 and BIST BANKS indexes are also included.

To assess the weak form of BIST banking sector efficiency, the weekly adjusted closing prices of selected stocks and indexes are collected from finance.yahoo.com and investing.com. The study period covers from January 4,210 to December 20, 2019. Therefore, a total of 520 observations for each stock and index is analyzed. The weekly observation for ISCTR is found starting from February 15, 2010, and a total of 514 weekly observations analyzed. The collected data is analyzed using autocorrelation, run test and unit root tests such as Augmented Dickey-Fuller (ADF), Phillips-Perron test (PP) and Kwiatkowski-Phillips SchmidtShin (KPSS).

The autocorrelation test results indicated that only VAKBAN and YAKBNK do not have any autocorrelation. Therefore, depending on autocorrelation, they are efficient at the weak form of efficiency during the study period. On the other hand, the runs test result showed that only AKBANK and GARAN does not follow the random walk hypothesis and the other six samples are efficient at the weak form of efficiency. Finally, the unit root tests such as ADF, PP and KPSS results indicated that all samples do not follow the random walk hypothesis and they are not efficient at the weak form of market efficiency. BISTt 100 and BIST BANKS indexes are not efficient according to autocorrelation and unit root test results. Therefore, the three types of tests employed in this study showed a distinctive result and it is difficult to give a general conclusion regarding the efficiency of BIST Banking sector in the weak form. In light of these finding, technical analysts can beat the market by analyzing the BIST banking sector stocks' historical prices.

\section{REFERENCES}

Aga, M., \& Kocaman, B. (2008). Efficient market hypothesis and emerging capital markets: empirical evidence from Istanbul Stock Exchange. International Research Journal of Finance and Economics, 13(1), 131-144.

Akgün, A., \& Şahin, I. E. (2017). The Testing of Efficient Market Hypothesis in Borsa Istanbul. Analele Universitatii" Constantin Brancusi" din Targu Jiu. Serie Litere si Stiinte Sociale, (2), 35-48.

Aliyev, F. (2019). Testing Market Efficiency with Nonlinear Methods: Evidence from Borsa Istanbul. International Journal of Financial Studies, $7(2), 27$.

Al-Jafari, M. K. (2013). The random walk behavior and weak-form efficiency of the Istanbul Stock Market 1997-2011: empirical evidence. International Journal of Management, 30(3), 169.

Alparslan, S. M. (1989) Tests of Weak Form Efficiency in İstanbul Stock Exchange, Unpublished MBA Thesis, Bilkent University,Ankara, Turkey.

Arltová ,M. \& Fedorová, D. (2016). Selection of unit root test on the basis of length of the time series and value of AR (1) parameter. Statistika, 96(3), 3.

Autocorrelation. BusinessDictionary.com. Retrieved December 18, 2019, from BusinessDictionary.com website: http://www.businessdictionary.com/definition/autocorrelation.html

Aydin, N., Başar, M. \& Coşkun, M. (2015). Finansal Yönetim. Detay Yayıncılık, 2. Baskı, Ankara.

Balaban, E. (1995). Informational efficiency of the Istanbul Securities Exchange and some rationale for public regulation. The Central Bank of The Republic of Turkey Research Department Discussion Paper, 9502, 39-67.

Batten, J. A., Fetherston, T. A., \& Szilagyi, P. G. (Eds.). (2004). European fixed income markets: Money, bond, and interest rate derivatives (Vol. 665). John Wiley \& Sons.

Bauer, G. (2004). A Taxonomy of Market Efficiency. Bank of Canada Financial System Review, 37-40. 
BIST (2019). Indices. Retrieved on December 17, 2019 from https://www.borsaistanbul.com/en/indices

BIST (2019). Markets. Retrieved on December 17, 2019 from https://www.borsaistanbul.com/en/products-and-markets/markets

Buguk, C., \& Brorsen, B. W. (2003). Testing weak-form market efficiency: Evidence from the Istanbul Stock Exchange. International review of financial analysis, 12(5), 579-590.

Bulut, Ü. (2016). Testing the Weak Form of the Efficient Market Hypothesis: The Case of Turkey.

Canbaş, S., \& Doğukanlı, H. (2017). Finansal pazarlar: finansal kurumlar ve sermaye pazarı analizleri. Altıncı Baskı. Karahan Kitabevi.

Carp, L. (2012). Can stock market development boost economic growth? Empirical evidence from emerging markets in Central and Eastern Europe. Procedia Economics and Finance, 3, 438-444.

Chambers, N. (2006). The Creation, Development And Operation Of The Istanbul Stock Exchange. Mali Cozum Dergisi (Ozel Sayi), $76,141-77$.

Cooray, A., \& Wickremasinghe, G. (2007). The efficiency of emerging stock markets: Empirical evidence from the South Asian region. The Journal of Developing Areas, 171-183.

Corder, G. W., \& Foreman, D. I. (2014). Nonparametric statistics: A step-by-step approach. John Wiley \& Sons.

Daver, G., Karacaer, M., \& Hülya, Ü. N. L. Ü (2013). Testing of BIST And TurkDEX: Random Walk and Market Efficiency. International Journal of Economics and Finance Studies, 5(2), 10-22.

Dickinson, J. P., \& Muragu, K. (1994). Market efficiency in developing countries: A case study of the Nairobi Stock Exchange. Journal of Business Finance \& Accounting, 21(1), 133-150.

Dimson, E., \& Mussavian, M. (1998). A brief history of market efficiency. European financial management, 4(1), 91-103.

Dufour, J. M., Lepage, Y., \& Zeidan, H. (1982). Nonparametric testing for time series: a bibliography. Canadian Journal of Statistics, 10(1), 138.

Eviews.com. (2019). User's Guide : Basic Data Analysis : Series : Correlogram. Retrived December 24 , 2019 from http://www.eviews.com/help/helpintro.html\#page/content/series-Correlogram.html

Fama, E. F. (1965). The behavior of stock-market prices. The journal of Business, 38(1), 34-105.

Fama, E. F. (1970). Efficient capital markets: A review of theory and empirical work. The journal of Finance, 25(2), 383-417.

Gozbasi, O., Kucukkaplan, I., \& Nazlioglu, S. (2014). Re-examining the Turkish stock market efficiency: Evidence from nonlinear unit root tests. Economic Modelling, 38, 381-384.

Gujarati, D. N. (2009). Basic econometrics. Tata McGraw-Hill Education.

Harvey, A. C. (2005). A unified approach to testing for stationarity and unit roots. Identification and Inference for Econometric Models, 40325.

Investment Support and Promotion Agency of Turkey (2015). The Financial Services Sector in Turkey. Retrieved from https://www.flandersinvestmentandtrade.com/export/sites/trade/files/market_studies/The\%20Financial\%20Services\%20Sector\%20in\%20 Turkey.pdf

Kapusuzoglu, A. (2013). Testing weak form market efficiency on the Istanbul stock exchange (ISE). International Journal of Business Management and Economic Research, 4(2), 700-705.

Kendall, M. G., \& Hill, A. B. (1953). The analysis of economic time-series-part i: Prices. Journal of the Royal Statistical Society. Series A (General), 116(1), 11-34.

Khandoker, M. S. H., Siddik, M. N. A., \& Azam, M. (2011). Tests of weak-form market efficiency of Dhaka stock exchange: evidence from bank sector of Bangladesh. Interdisciplinary Journal of Research in Business, 1(9), 47-60.

Kiliç, Ö. G. D. S. B. (2005). Test of the weak form efficient market hypothesis for the Istanbul stock exchange by markov chains methodology. Çukurova Üniversitesi Sosyal Bilimler Enstitüsü Dergisi, 14(1), 333-342.

Malkiel, B. G. (1989). Efficient market hypothesis. In Finance (pp. 127-134). Palgrave Macmillan, London.

Mobarek, A., \& Keasey, K. (2000, May). Weak-form market efficiency of an emerging Market: Evidence from Dhaka Stock Market of Bangladesh. In ENBS Conference held on Oslo (pp. 1-30).

Muslumov, A., Aras, G., \& Kurtulus, B. (2003). Evolving market efficiency in istanbul stock exchange. Istanbul Technical University Selected Articles, 271-291.

Nkoro, E., \& Uko, A. K. (2016). Autoregressive Distributed Lag (ARDL) cointegration technique: application and interpretation. Journal of Statistical and Econometric Methods, 5(4), 63-91. 
Palachy, S. (2019). Towards Data Science. Detecting stationarity in time series data. Retrive on Dcember 2, 2019 from https://towardsdatascience.com/detecting-stationarity-in-time-series-data-d29e0a21e638

Panas, E. E. (1990). The behaviour of Athens stock prices. Applied Economics, 22(12), 1715-1727.

PDP (2019). Indexes. Retrieved on December 17, 2019 from. https://www.kap.org.tr/en/Endeksler

Pilbeam, K. (2018). Finance \& financial markets. Macmillan International Higher Education.

Roberts, H. V. (1959). Stock-market" patterns" and financial analysis: methodological suggestions. The Journal of Finance, 14(1), 1-10.

Samuelson, P. A. (1965), Proof that properly anticipated prices fluctuate randomly, Industrial Management Review 6(2), 41-49.

Saymeh, A. A. F. (2013). Empirical Testing for Weak Form Hypothesis of Emerging Capital Markets: A Comparative study of Jordan's ASE and Turkey's BORSA IST. International Journal of Empirical Finance, 1(2), 20-26.

Sjö, B. (2008). Testing for unit roots and cointegration. Lectures in Modern Econometric Time series Analysis.

Stengos, T., \& Panas, E. (1992). Testing the efficiency of the Athens Stock Exchange: Some results from the banking sector. Empirical Economics, 17(2), 239-252.

Stephanie (2016). Statistics How To. Serial Correlation / Autocorrelation: Definition, Tests. Retrieved December 21, 2019, from https://www.statisticshowto.datasciencecentral.com/serial-correlation-autocorrelation/

Stephanie (2018). Statistics How To. Ljung Box Test: Definition. Retrieved December 21, 2019, from https://www.statisticshowto.datasciencecentral.com/ljung-box-test/

Syczewska, E. M. (2010). Empirical power of the Kwiatkowski-Phillips-Schmidt-Shin test (No. 45).

Tas, O., Atac, C.G., (2019). Testing random walk hypothesis for Istanbul stock exchange. PressAcademia Procedia (PAP), V.9, p.48-53

Tintner, G. (1965). Introduction to Econometrics. Vvedenie v ekonometriku, 361.

Virmani, V. (2004). Unit Root Tests: Results from some recent tests applied to select Indian macroeconomic variables.

Wang, Y. (2003). Nonparametric tests for randomness. ECE, 461, 1-11.

Yücel, Ö. (2016). Finansal piyasa etkinliği: Borsa İstanbul üzerine bir uygulama. International Review of Economics and Management, 4(3). 